\title{
Design and use of a Fatigue Test Machine in Plane Bending for Composite Specimens and Bonded Joints
}

\author{
G. Di Franco, G. Marannano, A. Pasta and G. Virzì Mariotti \\ Università degli Studi di Palermo, Dip. di Meccanica, \\ Viale Delle Scienze - 90128 Palermo \\ Italy
}

\section{Introduction}

Polymeric and composites materials are used increasingly as structural parts in industry and therefore many informations on mechanical properties (creep, relaxation, fatigue life) are necessary.

Composite materials behavior subjected to fatigue load is very complex due to non homogeneous and anisotropic properties, and it has been studied for a long time; however, composite materials design is still based on very long fatigue tests and high safety factors are used.

Composites industry uses various types of resin (usually epoxy or polyester resin) and reinforced fibers (usually fiberglass). Many industrial components and consumer goods are made in this way, such as parts for boats, car components, etc.

Composites with polymer matrix are used by the industries with much performed resins and stubborn and rigid reinforced fiber. Composite materials are used primarily in aerospace, military and automotive industries, however, are also utilized in sports such as golf, fishing, skiing (and snowboarding) and in the naval industry (Marannano \& Virzì Mariotti 2008).

These materials have very high mechanical properties such as low weight, high strength and stiffness, good formability and high design flexibility. Many theoretical studies (Van Paepegem \& Degrieck, (b) 2001; Van Paepegem \& Degrieck, 2002 ;Marannano \& Pasta 2006; Natarajan et al. 2005) are dedicated to the study of crack propagation, applying the concepts of fracture mechanics. Fatigue failure can be described as a sequence of two phases:

- crack formation;

- crack propagation.

The crack propagation has been studied carefully, ignoring the formation crack, and precracked specimens are used for this purpose; the study requires the development of equipping, methodologies and specialist analysis. Fatigue studies usually require several days (sometimes weeks) of load cycles to obtain an appreciable damage. The tests show inhomogeneous results, so it is necessary to do many repetitions to get a more accurate 
estimate of fatigue life. In this case it is very important to develop a specific approach to fatigue tests based on the use of materials testing machines (FTM) to avoid the utilization of expensive hydraulic machines. Some ideal characteristics of FTM machines are:

1. adaptability to different geometries and rigidities of the specimens;

2. facility to perform various conditions of load (alternate or pulsatory load);

3. possibility to develop fatigue studies by recording the obtained data from different tested materials, which can be applied any criterion to predict the fatigue life;

4. possibility to measure strains;

5. low cost of instrumentation to perform several tests simultaneously;

6. adaptability of load frequency.

This chapter presents a FTM materials testing machine and experimental fatigue tests, to study composite materials behavior subjected to fatigue bending plane; the machine is designed to perform specific fatigue tests with different boundary conditions (such as frequency, elastic modulus, etc.). The development of a fatigue testing machine in plane bending starts with the need to perform multi-axial fatigue tests on metallic materials (Frustey \& Laserre, 1989) and to make fatigue-corrosion tests (Berchem \& Hocking, 2006), on aluminum alloys (Beck et at 2002; Van Paepegem \& Degrieck, (a) 2001) and on a-brass (Sugeta et al. 2006). It is very difficult to find specifics to FTM machines for composite and polymeric materials in the literature (Trotignon, 1995; Caligiana et al. 2003; Marannano et al. 2007), while applications on bonded joints are not frequent. Initially the properties of composite materials under static conditions are evaluated, then fatigue curves are obtained for different loading conditions. Wöhler curve are obtained using N10 criterion, corresponding to the loss of $10 \%$ of the initial stiffness. Finally, the model of residual resistance was adopted as a tool to describe the fatigue behaviour.

\section{Materials testing machine (FTM)}

\subsection{General presentation}

Fatigue tests on plastics and composite materials must be performed under similar conditions to those operational (frequency, environmental conditions, specimen geometry, etc.). Materials testing machine for dynamic load in alternate plane bending is constituted by three modules:

1. the first module (or control module) generates a sinusoidal movement;

2. the second module can modify loading conditions;

3. the third module (or module data acquisition) measures the stress (load) and analyzes the values through the computer to plot the curves of the load versus the number of cycles.

\subsection{The first module (or control module)}

Figure 1 shows the built and used structure to perform fatigue tests in plane bending. A three-phase electric motor (1) with inverter (2) (to adjust the frequency of loading from 0.04 to $23 \mathrm{~Hz}$ ) rotates a pulley (with throat z) that, via a link belt (3), places in rotation an intermediate shaft (4) with transmission ratio equal to one. The transmission ratio is verified by optical tachometer, monitoring the number of rotations of the crankshaft and the corresponding speed of the drive shaft. Power transmission by belt ensures the electrical insulation of the specimen by the engine, with particular advantage if the specimens contain metal or carbon. An eccentric cam system (5) allows to transform the circular motion in a 
purely symmetric and oscillating motion of the solicitation rod (6). The specimen to be tested (7) is stuck to a rigid frame at one end (8) and stressed by the rod load at other end.

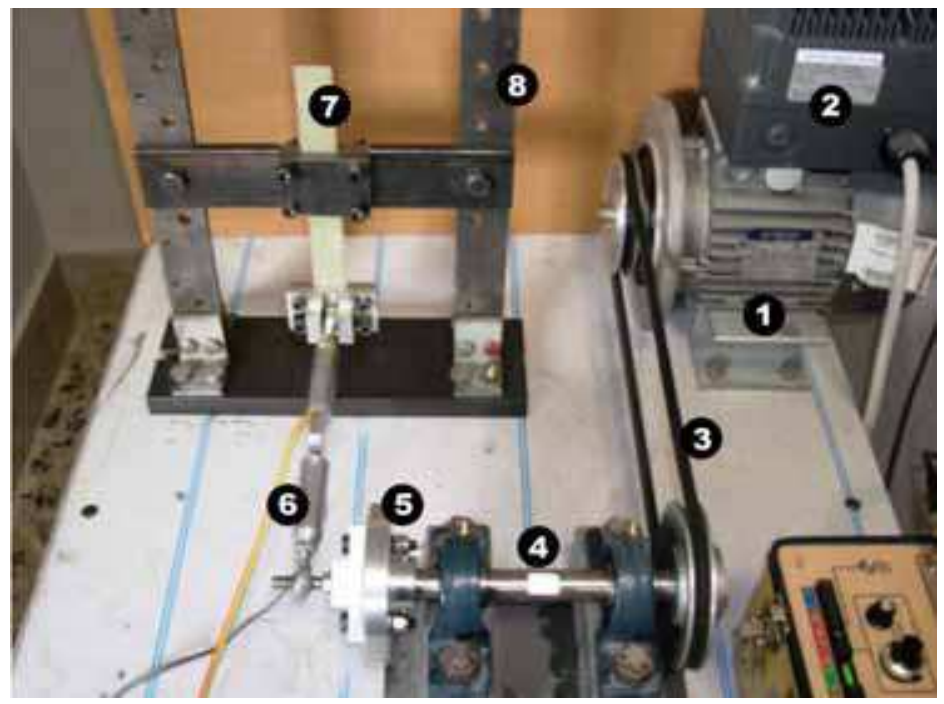

Fig. 1. Materials testing machine

Stress magnitude is determined by the distance between the points P (mobile) and Q (fixed) (Figure 2). It is possible to change load type (alternate or pulsatory) depending on the eccentricity and variable length of the connecting rod. The development of load-number of cycles is monitored at regular intervals or continuously, for all imposed displacement.

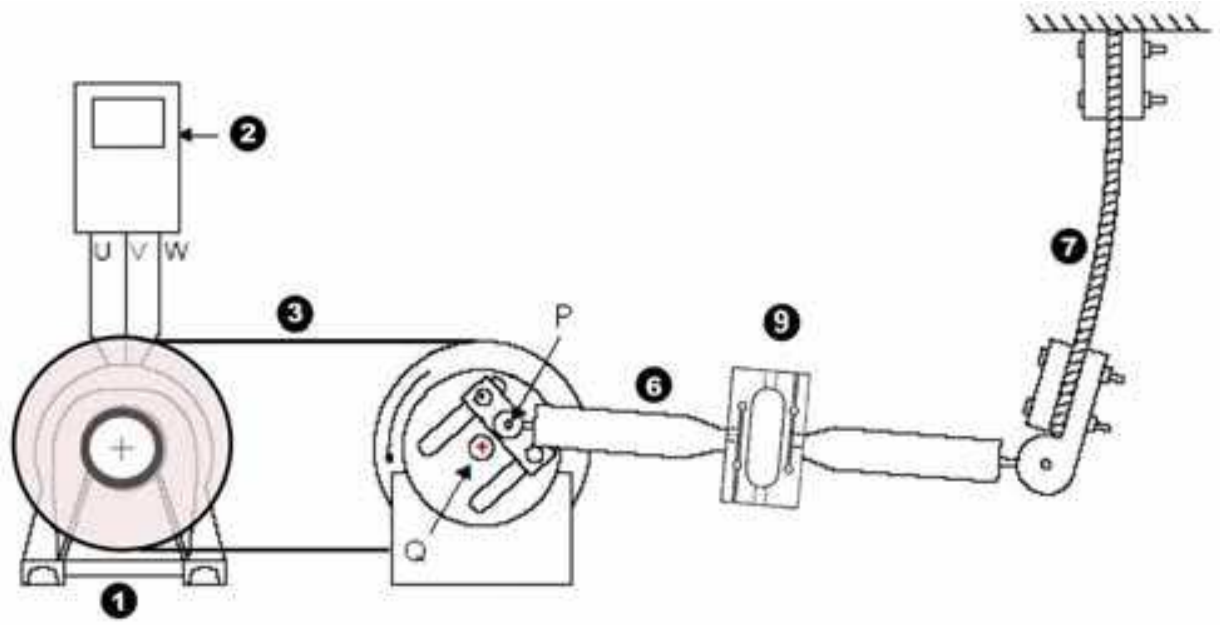

Fig. 2. Schematic representation of materials testing machine 


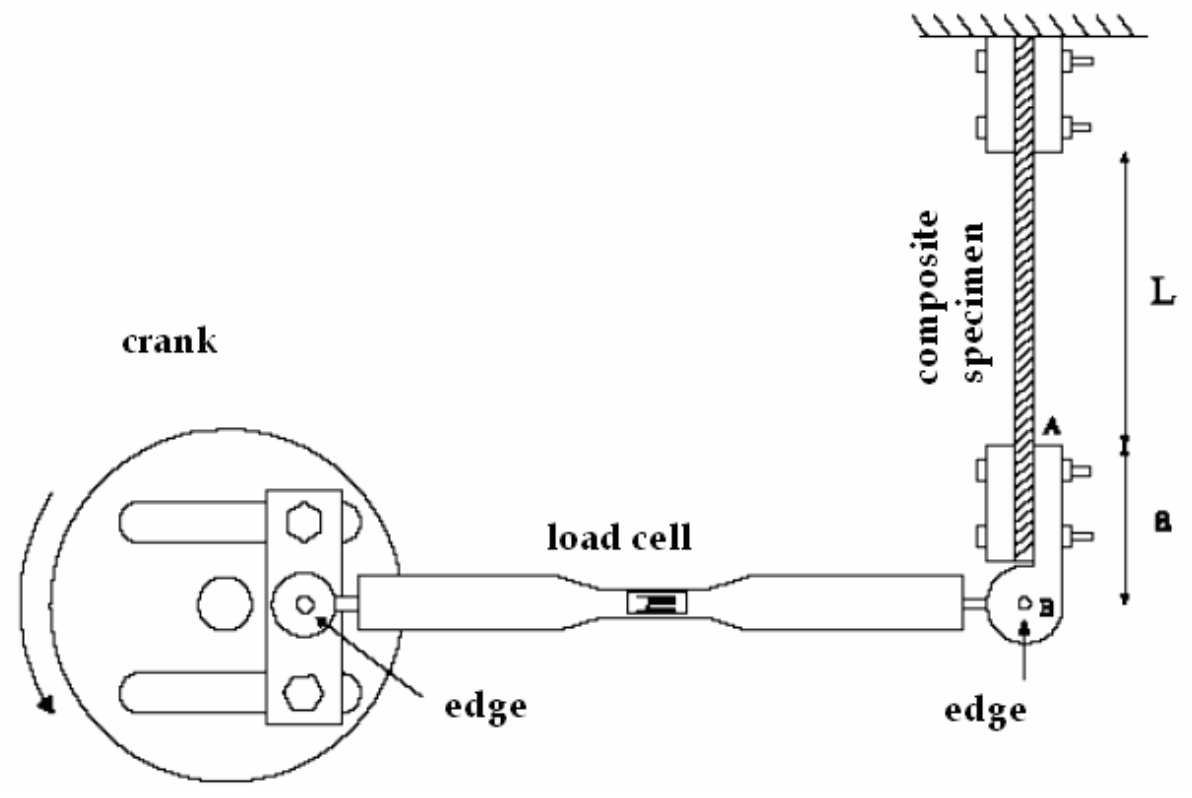

Fig. 3. Schematic representation of the second module

\subsection{The second module}

The second module (Fig. 3) allows to vary the length of the connecting rod and to modify some geometric values. The extension of the rod can be varied in a micrometer way in order to adjust the scale of imposed displacement and consequently the type of stress (alternate, symmetric or throbbing). In this way the deflection of the specimen can vary from zero up to a maximum value, quite apart from the load type. Moving the crossbar panel, tests on specimens of different lengths can be performed, with the maximum force depending on the power of the engine installed.

\subsection{The third module (or data acquisition module)}

The load values are monitored and registered by a dedicated acquisition system during the experimental tests. The whole system consists of a strain sensor (load cell), a strain indicator, a digital-analog connector and a computer. Special software, created and developed in LabView room, allows to record and display the values of variation of stiffness of the composite or the bonded joint, thus obtaining in real time the damage versus the time or cycles number. The decrease in stiffness is measured via the stress until specimen failure, operating with constant amplitude strain. Also it is possible to use any criterion of fatigue life of composite materials.

\subsection{Setting machine}

The device can perform tests under pulsatory or alternating loads with the "flexibility" of some organs. In particular, as shown in figure 4 , it is possible to increase the maximum displacement imposed to the test clamped the bar in the back of the two standing by the change in the position of horizontal beam (which allows the grasping of upper specimen). 

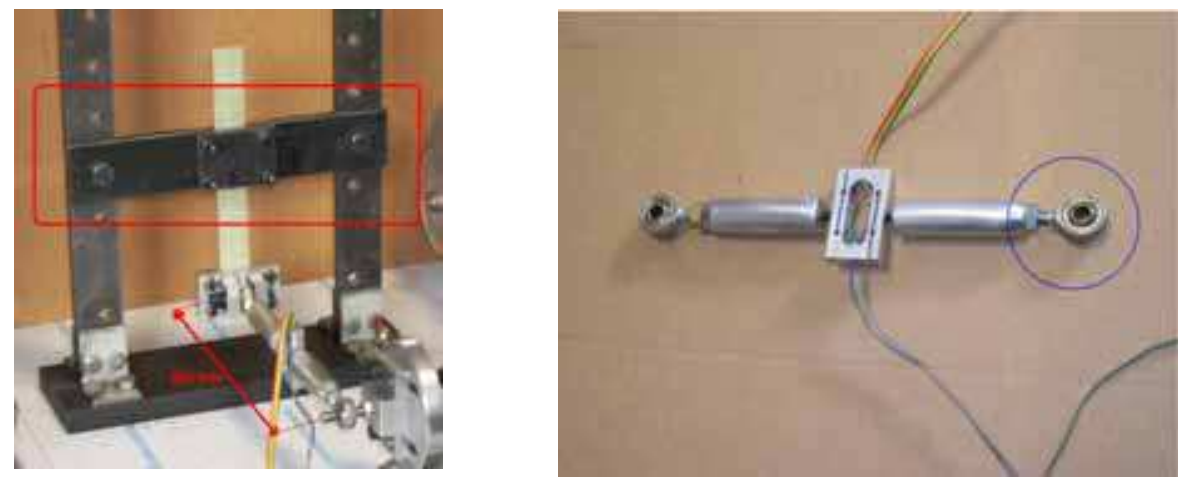

Fig. 4. Control system through horizontal beam (on the left) and joint (on the right)

Another way to change imposed movement is provided by joint (Fig. 4 on the right). One or both of the joints are screwed or unscrewed to adjust the distance between the eccentric and specimen, so it is possible to vary the minimum $\left(u_{\min }\right)$ and maximum $\left(u_{\max }\right)$ imposed displacement. Also (Fig. 4 on the left) the distance between the eccentric and the system of lower grasping specimen is illustrated, approximately $250 \mathrm{~mm}$. Critical value of possible strain $\left(u_{\max }-u_{\min }\right)$ is $150 \mathrm{~mm}$ theoretically, equal to the sum of twice distance QP (fig. 2), crank radius formed by the eccentric with the elongation imposed at the joints.

\section{Load cell}

Load cell is constituted by a metal body that takes different forms according to the following requirements: amplitude of measured load; applications type; environmental conditions.

Two cells for two different load values are designed: in aluminum (Fig. 5) for stresses not exceeding $50 \mathrm{~N}$ and in steel for stresses not exceeding $200 \mathrm{~N}$. 3D solid modeling was obtained using Solid Edge, and analysis was performed by ANSYS to verify the design and the stress response of the transducer, obtaining the definitive optimized configuration.

Operating with constant amplitude of deformation (strain control), the decrease in stiffness is proportional to the variation of the load recorded by the load cell, from the beginning of the test until the complete damage of the specimen.

Aluminium load cell just weights $25 \mathrm{~g}$ and is well suited for monitoring small loads; the demonstration is its resolution: $0.42 \mathrm{~g}$. Four electrical strain gauges having resistance of 350 $\Omega$ are placed in the hollow area; the basis of measurement is $3 \mathrm{~mm}$. The transducer also has two holes M5 (top and bottom holes) to connect it to material testing machine and two side holes (radius $4 \mathrm{~mm}$ ) to pass the cables connecting the strain gauges. Similar geometry to the aluminium transducer is used to realize the load cell in steel. Also in this case four electrical resistance strain gauges of $350 \Omega$ were used and the basis of measurement is $3 \mathrm{~mm}$. Also in this second case the weight remains relatively low and is equal to $59.9 \mathrm{~g}$.

3D solid model obtained by Solid Edge has been imported into the finite element code Ansys. The analysis was performed to verify the size of transducer. Figure 6 shows the longitudinal strain, interesting four strain gauges on the cell subjected to load equal to $200 \mathrm{~N}$ and Von Mises stress map obtained by ANSYS, when load cell (steel) is subjected to a load of $200 \mathrm{~N}$. 
The maximum strain is obtained in closeness of the fillet radius and therefore the strain gauges are positioned in these areas. Static safety factor are obtained 6.3 for the aluminium load cell and 3.5 for the steel load cell by the numerical study in ANSYS.
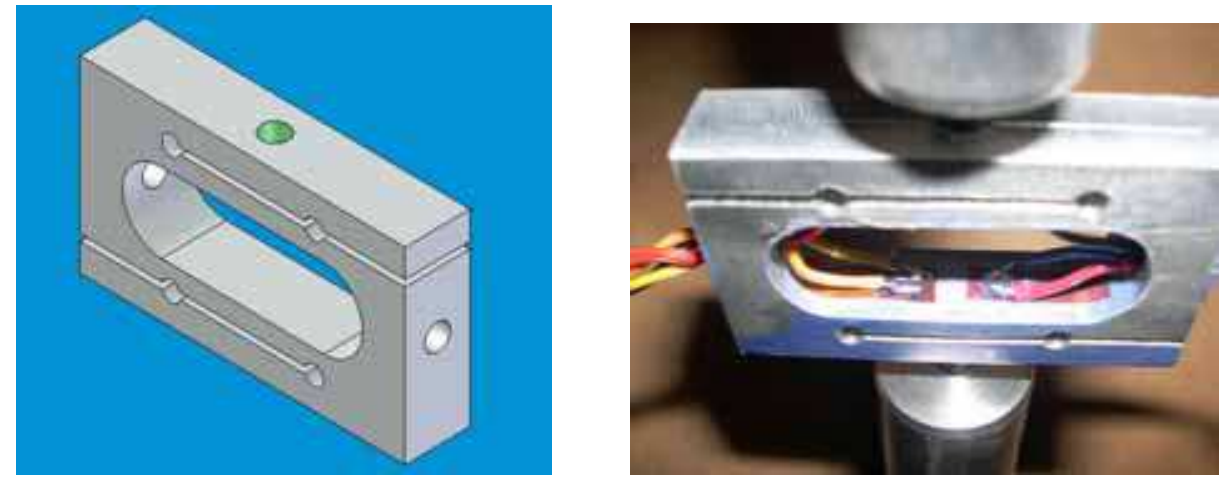

Fig. 5. 3D model of load cell (9) (on the left) and positioning of strain gauges (on the right
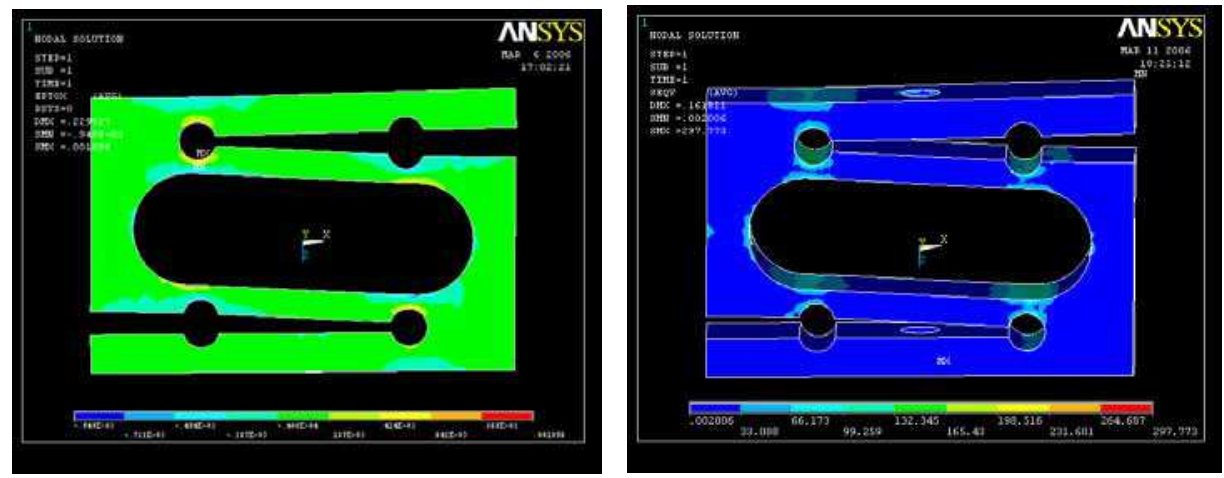

Fig. 6. Map of longitudinal strain (on the left) and of Von Mises stress (on the right)

\subsection{Load cell calibration}

Calibration involves the recording of output signal by the load cells, when loads are known. The aim is to derive calibration curve, allowing the correction of the output signal by cells, in order to read the exact value of the load acting in every direction. A load varying between a minimum and a maximum is applied at predetermined intervals; the calibration has been performed at least twice to verify measurements repeatability: calibration curve is draw in the case of correlation of the two tests, otherwise the data are interpolated by Ordinary Least Squares and another test is run to confirm the results. Calibration methodology is shown in the EN 10002/3 and ISO 376 rules, which are international standards of reference.

\section{Fatigue behavior of composite materials}

Unlike homogeneous materials, composites accumulate the damage in various parts rather than localized way, when subjected to fatigue load. In composite materials the fracture 
always does not start with the growth and development of macro-crack at an only point. Also there are good possibilities that cracks formation and propagation are already present within the materials (cracks in the matrix, broken fibres). Under fatigue load, these defects give rise to the formation of cracks and to their propagation. Defects growth is microstructural in these materials and includes the presence of cracks in the matrix, delamination and fibres breakage. Fatigue life prediction of composite materials is very difficult.

In unidirectional composites with not-axial loading (angle between $0^{\circ}$ and $90^{\circ}$ ), the apex of the crack is subjected to two displacement components: an opening normal mode and a sliding parallel mode to the fibres. The effects of two damage types depend on the loading angle. For example, crack propagation is only as opening mode with a load of $90^{\circ}$, while the crack propagation is only as sliding mode with an angle of $0^{\circ}$. Then there is mixed mode crack propagation for angles between $0^{\circ}$ and $90^{\circ}$. In multidirectional composite fibres failure is related to transverse fibres; the crack propagates through the interface of the layers, it causes a stress concentration. Multidirectional laminates also create induced stresses in the edges as a result of different elastic properties of layers, often increasing the delamination between planes.

\subsection{Failure mode}

In some cases the failure is coincident with rupture (brittle behaviour), in other cases it coincides with the deviation from linear elastic behaviour (ductile behaviour). Failure can occur in various modes:

1. broken fibres;

2. fibre-matrix separation (debonding);

3. crack of the matrix (typical of fatigue);

4. separation of the sheets (delamination).

Sometimes these failure modes occur separately, sometimes they coexist.

\subsection{Fatigue in composite materials}

The growing use of composite materials is mainly due to their high strength and stiffness, coupled with a low density compared with steel. The fatigue load involves the formation of cracks in the matrix and then in the fibres. Composite materials can show different combinations (fibre orientation) and forms, so the fatigue study is particularly complex and demanding.

The fatigue failure occurs first in brittle materials characterized by low values of strain, so the matrix is damaged before the formation of cracks. The fatigue failure can take various forms in composite materials: broken fibres, fibre-matrix interface failure, delamination, presence of cracks in the matrix. Cracks decrease the stiffness and strength of the composite materials. The formation and numbers of cracks depends on fibres orientation. In composite materials with different fibre orientation cracks arise first in the weaker plans and then in other plans until the stronger.

Fibreglass composite materials have a greater versatility of geometry, but laminates offer a lower stiffness and static strength due to the distortion of fibreglass. Another possible reason is the percentage of fibres that is less than $60-65 \%$.

\subsection{Fatigue graphs: load-number of cycles curves}

The most common method to present fatigue dates is to plot stress $(S)$ versus the number of cycles $(\mathrm{N})$, these graphs are called S-N curves. The ordinate is usually the maximum stress 
or stress range. The abscissa is usually the number of cycles to failure for fixed cycle of stress or deformation and it is usually plotted on a logarithmic scale. Stress ratio (R) and test frequency $(\mathrm{Hz})$ are kept constant for all the specimens. All materials have a negative slope, so the number of cycles to failure increases with decreasing load. S-N curves of the composites generally depend on several factors:

- variables of material:

- $\quad$ material and fibre volume fraction $\left(\mathrm{V}_{\mathrm{f}}\right)$;

- $\quad$ matrix (resin);

- guidance plan;

- test variables:

- $\quad$ load type (traction or traction-compression);

- $\quad$ average stress;

- frequency;

- environmental conditions.

S-N curves usually are linear for less than one million life cycles and can be expressed by linear equations like this:

$$
\frac{\sigma_{a p p}}{\sigma_{\text {stat }}}=A+B \log N
$$

$\sigma_{\text {app }}$ and $\sigma_{\text {stat }}$ are applied and static stress respectively, A and B are constants that depend on the material. The fatigue limit depends on many factors such as the reinforcement type, matrix and fibres orientation. Unlike metallic materials, stress-number of cycles curves of composite materials are not characterized by a fatigue limit, in fact, these curves show a continuous gradient (downwards) towards zero as the number of cycles. The criteria for the fatigue life are numerous for composite materials; usually the criterion $\mathrm{N}_{10}$ is used, which indicates the number of cycles to have a decrease in stiffness of $10 \%$. In other words, the criterion $\mathrm{N}_{10}$ is the number of cycles required for the stress drops to $90 \%$ of initial value.

A composite material, in the its simplest form, has unidirectional fibres aligned with the direction of stress (load on axis); the fibres bear most of the load in the case of fatigue load. It is easy to think that the fatigue behaviour of a composite depends exclusively on the fibre; in reality the experimental results show that the fatigue behaviour of a composite material depends mainly on the stress in the matrix. The fatigue life increases with increasing angles layers (Marannano \& Virzi' Mariotti, 2008) in multidirectional composite materials. The presence of fibres causes damage and delamination among layers in the case of transverse loads and off-axis.

\subsection{Composite damage}

The damage process has two predominant phases: an initial stage where the development of non-interacting cracks leads to the Characteristic Damage State (CDS), in which a model of stable crack is developed. In the second phase, cracks of different nature interact among them with the increase of the number of cycles, causing an increase in localized cracks and the consequent fracture.

In the first phase, the cracks of matrix are generated in the plane if stresses, orthogonal to the fibres direction, exceed the strength of the matrix. These cracks usually occur in composites with brittle matrix (epoxy resin), but can also occur if the matrix is ductile (metal matrix). 
Innate micro defects in the material increase continuously with fatigue loads, and when the size of the defects reaches a characteristic dimension, a first crack (original or primary crack) is formed at the beginning of CDS. First cracks in the matrix are due to consequent development of the damage under fatigue loads, and are a basis for the development of localized defects, buckling and growth of delamination in compressive loads.

The CDS is a property of the laminate, and it depends on the properties of individual layers, thickness and sequence. The CDS is independent of the loading history, boundary conditions, treatments, residual stress and humidity. It is the starting point for those processes that control the strength, stiffness and fatigue life of the laminates. It also represents a state of the damage that can be accurately described.

Characteristic of second phase is the delamination. Primary cracks propagate due to the propagation of the secondary cracks near the interface of the layers. Secondary cracks are usually perpendicular to primary and are due to stress directed along primary axis of the cracks. High interlaminar stresses generate interlaminar cracks that cause the delamination within the laminate, in the region where there are primary and secondary cracks. Then the fibres break heavily (third phase), and cause the final break. In many cases, it was noted that two thirds of the broken fibre occur in the first third of total number of cycles. However, the final failure occurs when the broken fibres are aligned with principal stress. The phases of the damage model do not occupy separate regions within material life; however, the cracks formation in the matrix characterizes the first phase of the damage model while the delamination characterizes the second phase.

\section{Experimental procedures}

\subsection{Realization of the laminates}

Quasi-isotropic and reinforced aluminium specimens have been used in experimental tests (Vasek et al., 1997). The vacuum bag technique has been used to implement the laminates (Marannano \& Virzi' Mariotti, 2008) with a polyester resin, since this resin is very used in shipbuilding for its low cost.

The catalyst (2-3\% in volume) is added to make the resin more viscous and to reach a state where it is not more liquid: this is the gel point. The resin hardens to obtain the hardness and final properties; the reaction is accompanied by heat generation that increases reaction time, the process is known as curing. The construction of reinforced aluminium laminates is quite similar to quasi-isotropic composite materials, except the curing treatment, that is done at room temperature due to the different coefficients of thermal expansion that characterize the composite and aluminium, with consequent formation of residual stresses and possible cracks inside the specimens.

\subsection{Basic concepts}

An appropriate acquisition system was made to monitor the parameters of material damage during the experimental tests.

Induced stresses are monitored with an appropriate acquisition system during the tests (continuously or not, as appropriate). This system is made of a load cell, a "strain indicator", a digital-analog connector and a computer. Dedicated software can record and show the values of the material resistance, and so it is possible to have the load-number of cycles curves in real time. The acquisition software (Labview) records input signal and it shows the evolution of signals peak with the number of cycles at regular intervals through the connector, so it is possible to study the yielding of the specimen during the test. 


\subsection{First campaign of experimental test}

\subsubsection{Quasi-isotropic laminates}

The first campaign of experimental test has the aim to evidence the better quality of the Glare respect to the optimized composite laminates. Table 1 shows the characteristics of composite materials to perform the tests. It shows the calculation performed in Excel to determine the volume fraction of fibres. The value $69.21 \%$ was achieved using the vacuum bag technique; in fact it can not get these properties with the normal lay-up at room temperature.

\begin{tabular}{|l|l|c|}
\hline \multirow{4}{*}{ Size laminate } & Nr. layers & 12 \\
\cline { 2 - 3 } & thickness $[\mathrm{mm}]$ & 3 \\
\cline { 2 - 3 } & length $[\mathrm{mm}]$ & 150,6 \\
\cline { 2 - 3 } & width $[\mathrm{mm}]$ & 259 \\
\hline \multirow{4}{*}{ Weight } & layers weight $[\mathrm{g}]$ & 202,9 \\
\cline { 2 - 3 } & fibres specific weight $\left[\mathrm{g} / \mathrm{m}^{\wedge} 2\right]$ & 300 \\
\cline { 2 - 3 } & fibres weight $[\mathrm{g}]$ & 140,42 \\
\hline \multirow{2}{*}{$\%$} & \% fibres weight & 69,21 \\
\cline { 2 - 3 } & \% resin weight & 30,79 \\
\hline
\end{tabular}

Table 1. Properties of quasi-isotropic composite materials

Particular laminates are quasi-isotropic, where the stiffness is independent of considered direction. They must have: a total number of laminates $n$ greater or equal to 3 and laminates of the same constitution and thickness; the angle $\Delta \theta$ between the two laminates must be constant (angularly equidistant laminates). The name does not depend on the fact that these laminates can have small variations of the stiffness with the direction, but on the fact that they have isotropic behaviour with respect to traction-compression and not respect to bending and torsion. Quasi-isotropic laminates can be obtained with an appropriated orientation of the fibres, for example a symmetric laminate that has 12 layers positioned according to the scheme $[+30 /+90 /+30]_{s}$ (total thickness $3 \mathrm{~mm}$ ). Half of the laminate is made of 6 layers spaced $60^{\circ}$ angularly (Van Paepegem \& Degrieck, 2001; Marannano \& Virzi' Mariotti, 2008)).

\begin{tabular}{|l|c|c|}
\hline & $\begin{array}{c}\text { Preimp. Unidir. } \\
\text { Fibers } \mathrm{S}_{2}\left(\mathrm{v}_{\mathrm{f}}=60 \%\right)\end{array}$ & $2024-\mathrm{T3}$ \\
\hline Young modulus $\mathrm{E}_{1}[\mathrm{GPa}]$ & 54,0 & 72,2 \\
\hline Young modulus $\mathrm{E}_{2}[\mathrm{GPa}]$ & 9,4 & 72,2 \\
\hline Ultimate strength $\sigma_{\mathrm{r}}[\mathrm{MPa}]$ & 2640 & 455 \\
\hline Ultimate strain $\varepsilon_{\mathrm{r}}[\%]$ & 4,7 & 19 \\
\hline Poisson Ratio $v_{12}$ & 0,33 & 0,33 \\
\hline Poisson Ratio $v_{21}$ & 0,0575 & 0,33 \\
\hline Shear modulus $[\mathrm{GPa}]$ & 5,55 & 27,6 \\
\hline Density $\rho\left[\mathrm{kg} / \mathrm{m}^{3}\right]$ & 1980 & 2770 \\
\hline
\end{tabular}

Table 2. Properties of glare constituents 


\subsubsection{GLARE}

The glare is a fibre-metal laminate; it is made of thin aluminium sheets with a thickness of 0.2-0.5 mm and fibreglass embedded in an epoxy matrix with a thickness of $0.125 \mathrm{~mm}$ and a nominal fibre volume fraction of $59 \%$.

Fibres direction is related to the lamination direction of aluminium sheets; $0^{\circ}$ or Longitudinal rolling direction (L) indicates that the fibres are placed in the direction of metal lamination, while $90^{\circ}$ or Longitudinal-Transverse rolling direction $(\mathrm{T})$ indicates that the fibres are oriented in transverse direction. Composite materials suffer a treatment in autoclave at high pressure and temperature. Mechanical properties of Glare depend on the characteristics of his constituents: aluminium and fibre, the most important properties are reported in table 2.

Mechanical properties of the adhesive are negligible if compared with the characteristics of embedded fibres, but the contribution of the adhesive characterizes the laminate performance strongly (Robinson \& Hodgkinson, 2000). It determines the force between metal and fibre layers and its detachment of the adhesive at the metal / fibre layer is one of the most frequent modes of laminate failure. The use of thin layers of aluminium (0.3 - 0.6 $\mathrm{mm}$ ) can not consider the thickness effects, as regards individual aluminium layers, and the laminate in its entirety. The method called "Metal Volume Fraction" (MVF) and "Theory of mixtures", it can determine the glare properties (Vasek et al., 1997).

\subsubsection{Experimental tests}

The specimens (Fig. 7) are made of fibreglass in the configuration quasi-isotropic $[ \pm 30 / \pm$ $90 / \pm 30]_{s}$ but also reinforced with aluminium sheets 6061-T6 [+30/-30/+ $90 /$ aluminium/+90/-30/+30] (glare). The laminate thickness is $3 \mathrm{~mm}$ in the first case, 3.1 $\mathrm{mm}$ in the second case, and epoxy resin was used for both specimen types. Composite specimens are made of 12 fibreglass layers, while the glare is composed of 6 fibreglass layers and aluminium sheet in the middle.

Geometric characteristics of the specimens are presented in table. 3. The tests were performed with different values of imposed strain. The following "shift ratio" was used to characterize each tests:

$$
R_{d}=\frac{u_{\min }}{u_{\max }}
$$

It is similar to stress ratio R. All experimental parameters are known with knowledge of the value of maximum deflection and the length $\mathrm{L}$ between the two attacks.

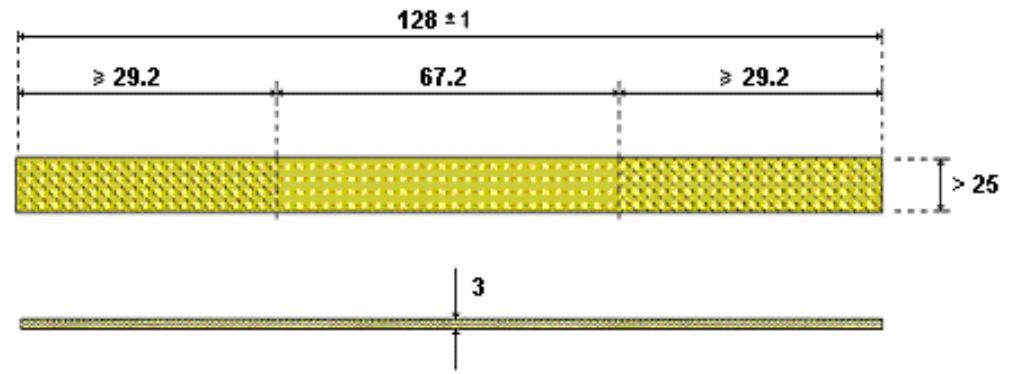

Fig. 7. Specimens geometry 


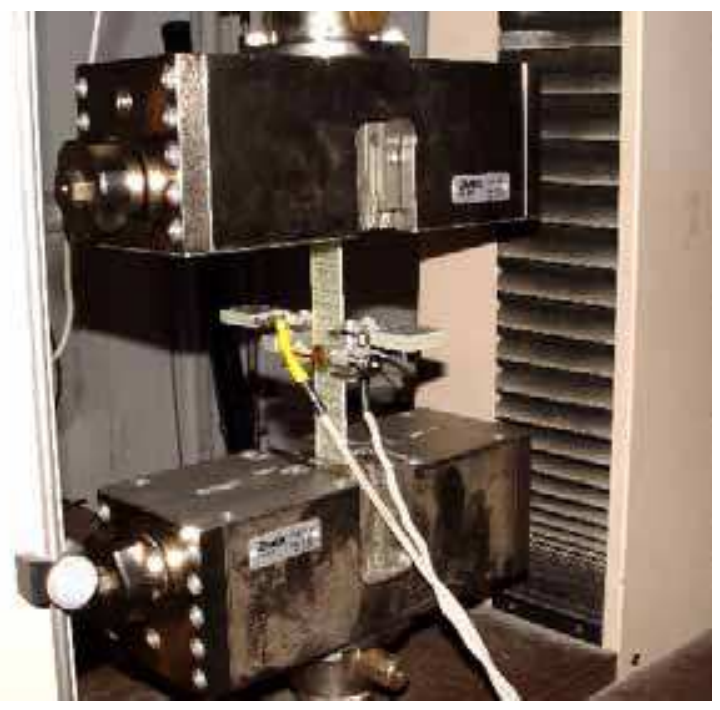

Fig. 8. Tensile test

Tensile tests were made to determine mechanical properties of both materials with Hounsfield material testing machine, equipped with proper grips for tensile test (Fig. 8). An extensometer was installed on the specimen to detect strains, while the load value is supplied by the load cell of $20000 \mathrm{~N}$.

Static and fatigue tests were performed on different types of composite materials. All specimens are made of polyester resin and fibreglass, the vacuum bag technique was used. Table 4 shows the characteristics of the materials.

All specimens were loaded with a sinusoidal signal generated by the machine. It was operated at a frequency $3 \mathrm{~Hz}$ and was constant for all experimental tests. Also 10 load cycles were monitored to minimize the influence of any spurious signals for each acquisition. It was calculated the stress magnitude and then the mean is done and any anomalous points is eliminated.

\begin{tabular}{|l|l|l|}
\hline & \multicolumn{1}{|c|}{ Composite Materials } & \multicolumn{2}{c|}{ Glare } \\
\hline Thickness [mm] & 3.00 & 3.10 \\
\hline Width [mm] & 25.60 & 25.30 \\
\hline Height [mm] & 129.1 & 127 \\
\hline Arm [mm] & 67.2 & 67.2 \\
\hline No. layers & 12 & 7 \\
\hline Weight [g] & 17.2 & 22.6 \\
\hline
\end{tabular}

Table 3. Geometrical characteristics of the specimens

Filtering was done with a low pass filter downstream of the signal acquisition, to cancel the influence of noise, always present, even if of negligible value, obtaining the signal in Figure 9. Finally, the program shows the magnitude of each load cycles, a very important element in the early cycles, where it is possible to have a rapid damage of the material. 


\begin{tabular}{|l|l|l|}
\hline Material properties & quasi-isotropic composite & Glare \\
\hline fiber/resin & Glass/polyester & Glass/polyester \\
\hline direction fiber & Equidirectional $\left(60^{\circ}\right)$ & Equidirectional $\left(60^{\circ}\right)$ \\
\hline fiber volume fraction & 69.21 & - \\
\hline $\begin{array}{l}\text { MVF (Metal Volume } \\
\text { Fraction) }\end{array}$ & 3,0 & 51.6 \\
\hline thickness [mm] & 16357 & 3.1 \\
\hline $\begin{array}{l}\text { longitudinal } \\
\text { module[MPa] }\end{array}$ & 38401 \\
\hline ultimate strength [MPa] & 303 & $\cong 200$ \\
\hline
\end{tabular}

Table 4. Material properties
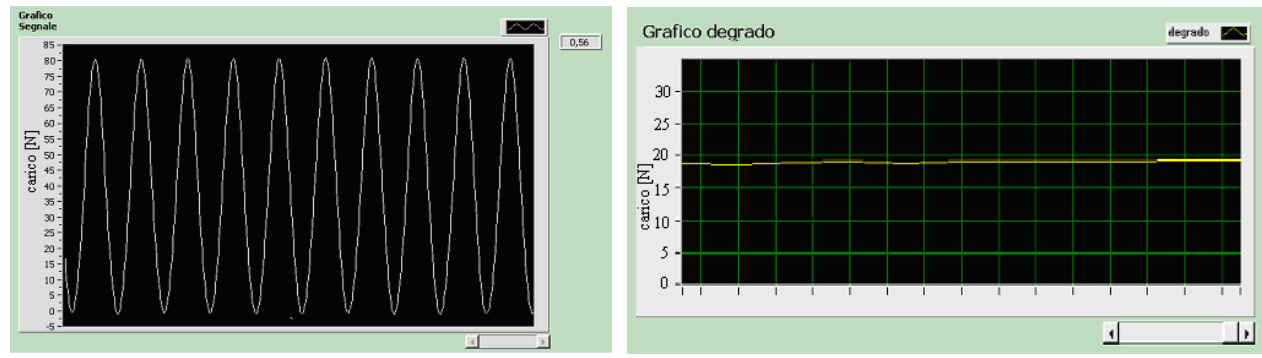

Fig. 9. Filtered signal (on the left) and monitored load (on the right)

Fatigue tests were performed with different values of imposed strain, all characterized by pulse bending. The displacement ratio defined by 2 was zero since the minimum displacement was zero. So the position of minimum displacement is depicted in figure 3 . Figure 10 shows load-number of cycles curves for almost-isotropic specimens, subject to pulsatory load with a maximum deflection $\left(\mathrm{u}_{\max }\right)$ from 10 to $27 \mathrm{~mm}$. Figure 11 shows similar results for glare specimens.

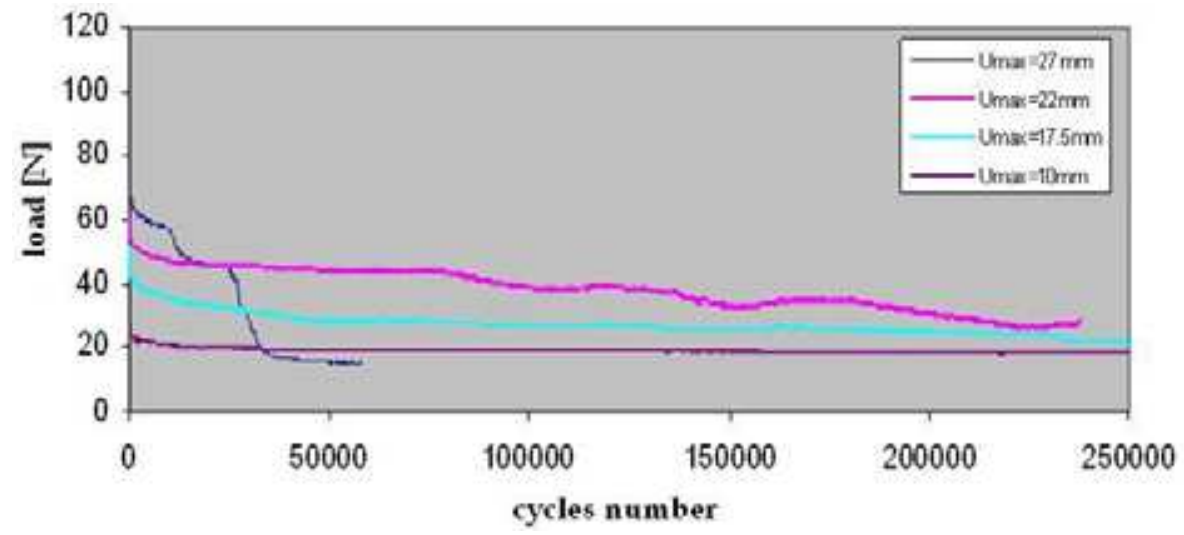

Fig. 10. Degradation in quasi-isotropic specimens 


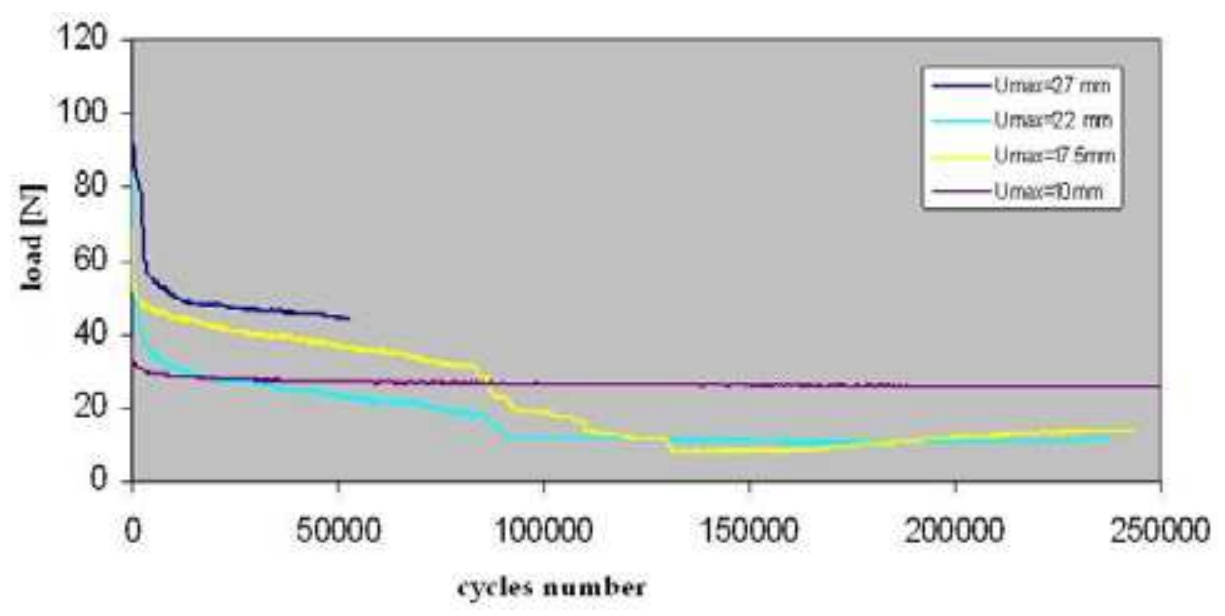

Fig. 11. Degradation in glare specimens

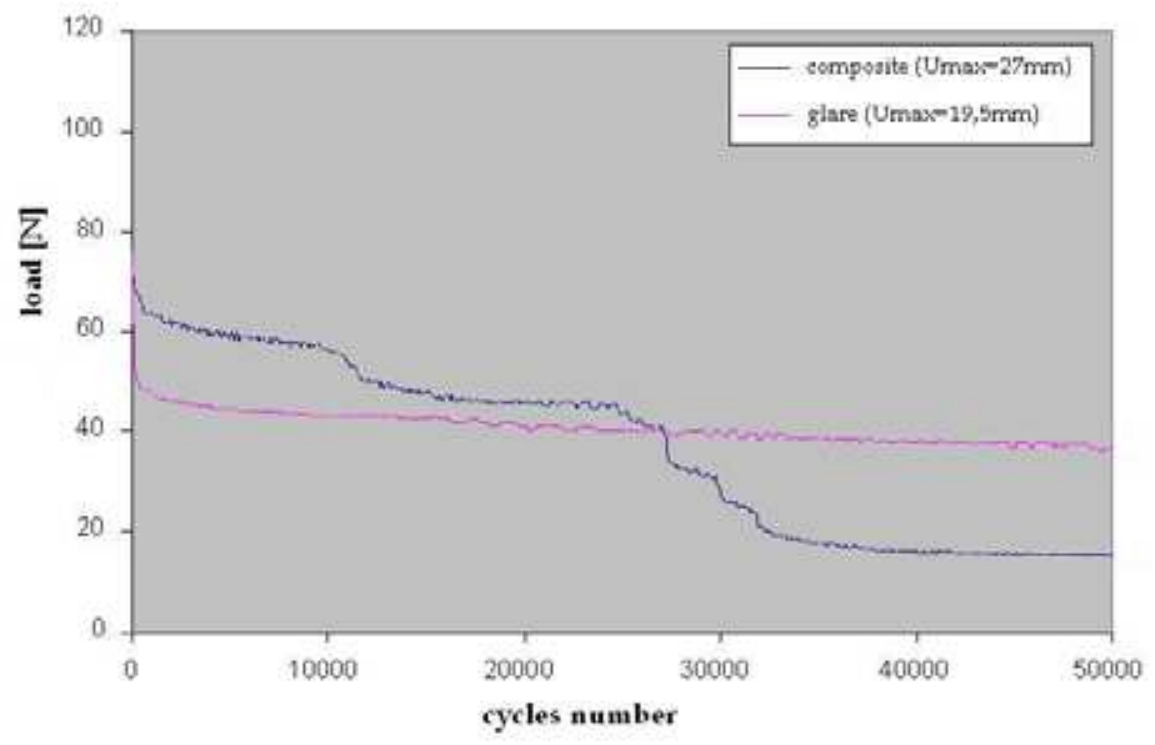

Fig. 12. Degradation of two specimen types for similar initial load

The behaviour of both materials is dependent on load highly. In fact there is a reduction of initial stiffness for small loads, and then a decrease of bearable load, which remains constant subsequently (Van Paepegem \& Degrieck, 2002). During experimental test (i.e. for 500,000 cycles) glare specimens support a higher load than that of the quasi-isotropic composite, with a similar trend. Imposing greater displacements, the load trend is more variable than in the case of composite specimens. In composite specimens there is a damage step, indicating a gradual breaking of layers, for loads exceeding a critical value $(60 \mathrm{~N})$; while the glare can maintain a larger value of the load for long time, after an initial damage. This is due to the 
presence of aluminium, which absorbs much of the load, leaving unstressed the glass fibres and allowing the specimen to maintain a non-negligible stiffness.

Figure 12 shows the degradation of specimens subjected to similar initial load. It shows as the glare presents a significant and unique collapse load, with few significant changes until the break; instead in the composite there is the sequential breaking of compressed fibres, with a step change of supported load. In all performed and analyzed tests there is always a localized damage in compressed fibres.

\subsection{Second campaign of experimental test (GLARE)}

A further study of glare is done using different specimens, to obtain a material that minimizes construction costs and has required characteristics. Laminates have been designed to study the propagation mode of the crack, and in these specimens the fibres are not in the direction of maximum strength to promote the investigated damage. 12 specimens are built, and are divided into:

- Nr. 6 specimens with configuration $[ \pm 30 / 90 / \mathrm{Al} / 90 / \pm 30]: 6+1$ layers, 6 unidirectional layers (fibreglass) with a quasi-isotropic configuration, 1 aluminium sheet type 6061-T6 (thickness $1 \mathrm{~mm}$ ) and total thickness is $3 \pm 0.1 \mathrm{~mm}$.

- Nr. 6 specimens with configuration $[ \pm 30 / \mathrm{Al} / 90]_{\mathrm{s}}: 6+2$ layers, 6 unidirectional layers (fibreglass) with a quasi-isotropic configuration, 1 aluminium sheet type 6061-T6 (each thickness $0.6 \mathrm{~mm}$ ) and total thickness $3.1 \pm 0.1 \mathrm{~mm}$.

Figure 13 shows the detail of frontal view, while the figures 14 and 15 show side views (profile) of the two specimen types, from those it is possible to see the sequence of various packaging types. The aluminium sheet is clearly visible in a central position in fig. 14, while the two aluminium sheets are visible in fig. 15.

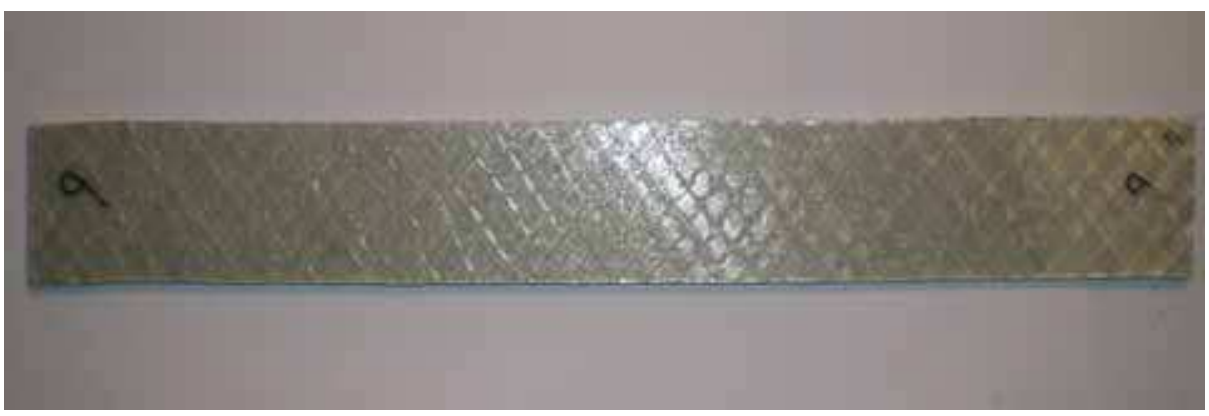

Fig. 13. Front view of specimen

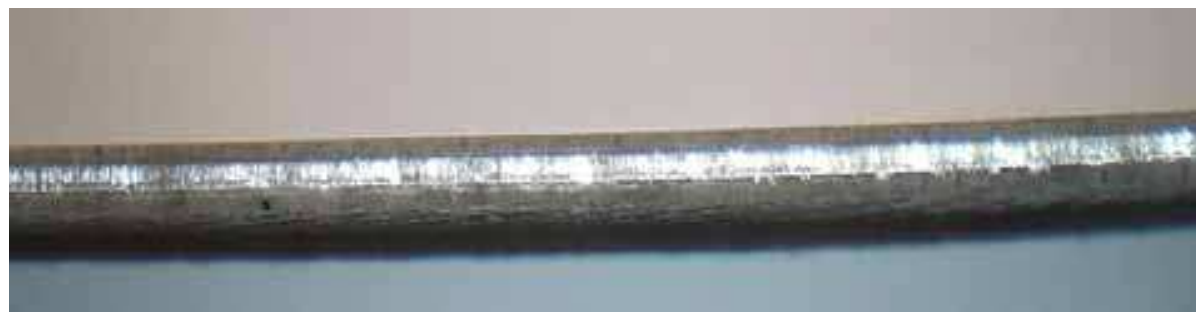

Fig. 14. Side view of specimen (type a) 


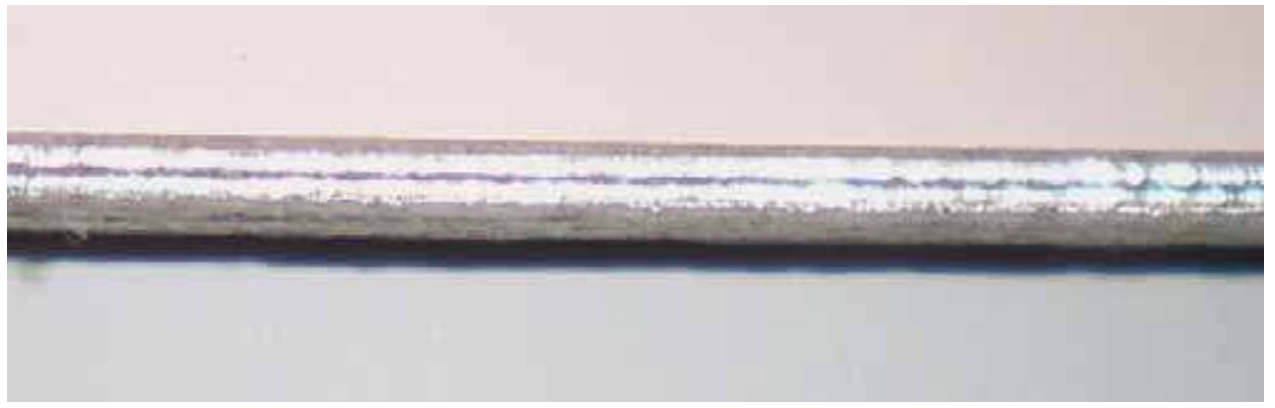

Fig. 15. Side view of specimen (type b)

The choice of these configurations has been made to have the specimens with similar thicknesses. Specimens geometries are shown in figures 16 and 17, and the size are listed in the table 3 .

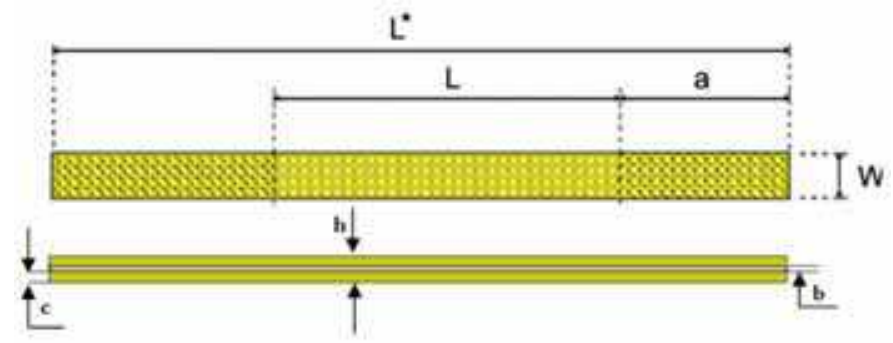

Fig. 16. Specimen geometry (type a)

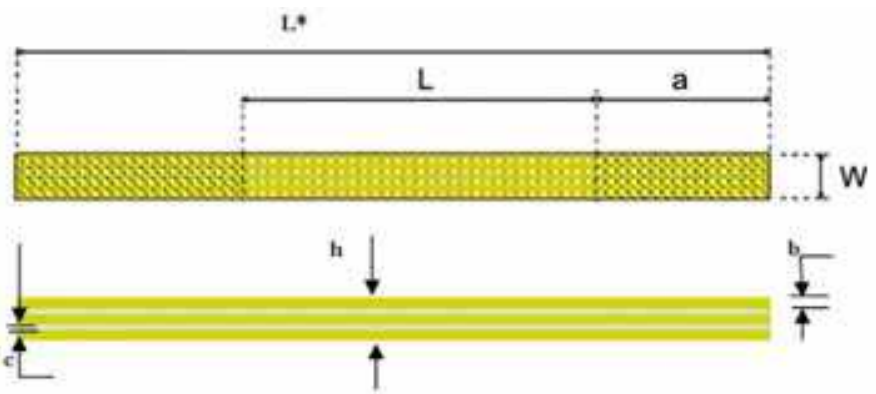

Fig. 17. Specimen geometry (type b)

\begin{tabular}{|c|l|l|l|l|l|l|l|l|}
\hline $\begin{array}{c}\text { Specimen } \\
\text { types }\end{array}$ & $\begin{array}{c}\text { No. } \\
\text { tests }\end{array}$ & $\begin{array}{c}\mathrm{W} \\
{[\mathrm{mm}]}\end{array}$ & $\begin{array}{c}\mathrm{L} \\
{[\mathrm{mm}]}\end{array}$ & $\begin{array}{c}\mathrm{L}^{*} \\
{[\mathrm{~mm}]}\end{array}$ & $\begin{array}{c}\mathrm{a} \\
{[\mathrm{mm}]}\end{array}$ & $\begin{array}{c}\mathrm{b} \\
{[\mathrm{mm}]}\end{array}$ & $\begin{array}{c}\mathrm{c} \\
{[\mathrm{mm}]}\end{array}$ & $\begin{array}{c}\mathrm{h} \\
{[\mathrm{mm}]}\end{array}$ \\
\hline (type a) & 6 & 25,5 & 120 & 230 & 37 & 1 & 1 & 3 \\
\hline (type b) & 6 & 25,5 & 120 & 230 & 37 & 0.6 & 0.6 & 3 \\
\hline
\end{tabular}

Table 3. Specimens size 


\begin{tabular}{|l|c|c|}
\hline \multirow{2}{*}{ Nr. test } & \multicolumn{2}{|c|}{ Initial load [N] } \\
\cline { 2 - 3 } & Glare (type a) & Glare (type b) \\
\hline 1 & 6,67 & 8,7 \\
\hline 2 & 17,3 & 16,1 \\
\hline 3 & 28,8 & 30,3 \\
\hline 4 & 29,1 & 40,2 \\
\hline 5 & & 83,2 \\
\hline
\end{tabular}

Table 4. Load imposed on Glare specimens (of course some tests are discarded because they are not reliable)

Also fatigue tests in bending were done for specimen types and for different values of imposed displacement as table 4 shows.

Figures 18 and 19 show the load curves versus the number of cycles, for the hybrid specimens with one and two aluminium sheets. It is possible to see as the damage is manifested in the first part of the curve mainly, which follows an asymptotic trend. Graphical comparison of experimental results gives an idea of the different behaviour that the two materials have during a fatigue load. The comparison of obtained results shows that the material type (a) has in initial phase a bigger damage than that of type (b) with similar displacements imposed (Fig. 20).

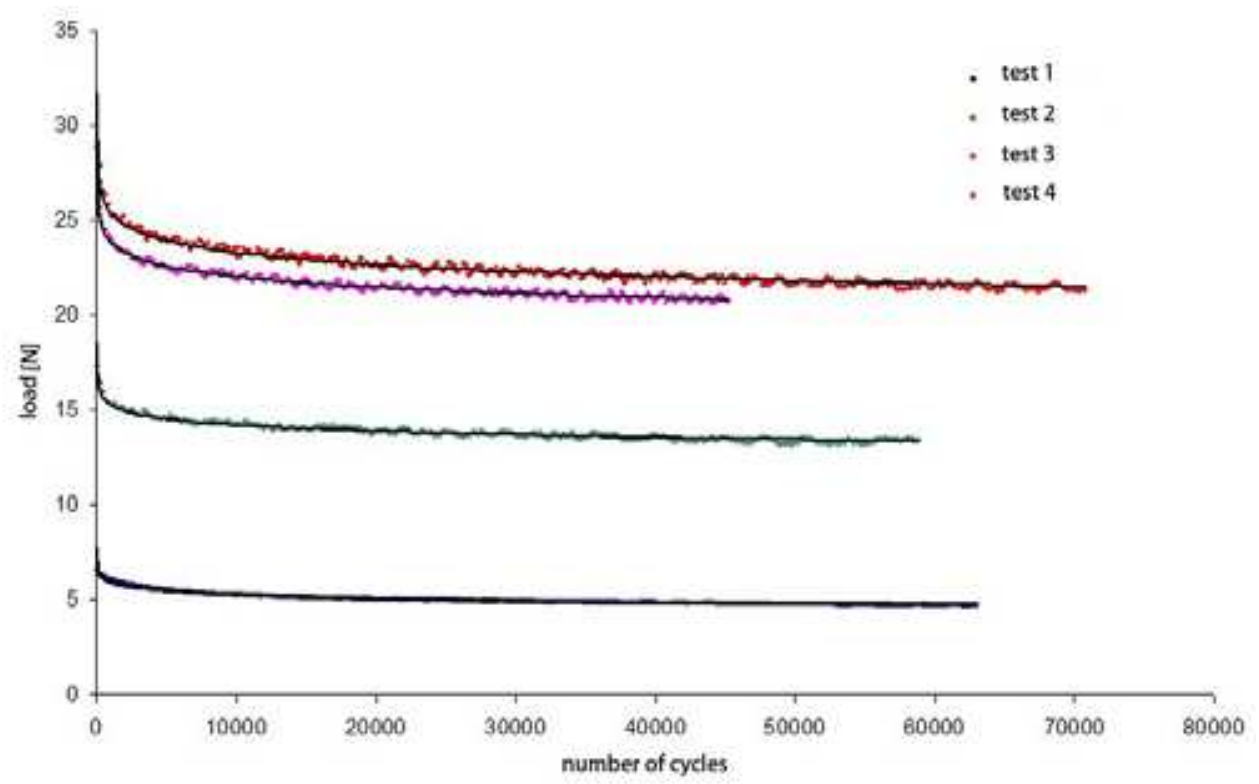

Fig. 18. Load curves versus the number of cycles (type a) 


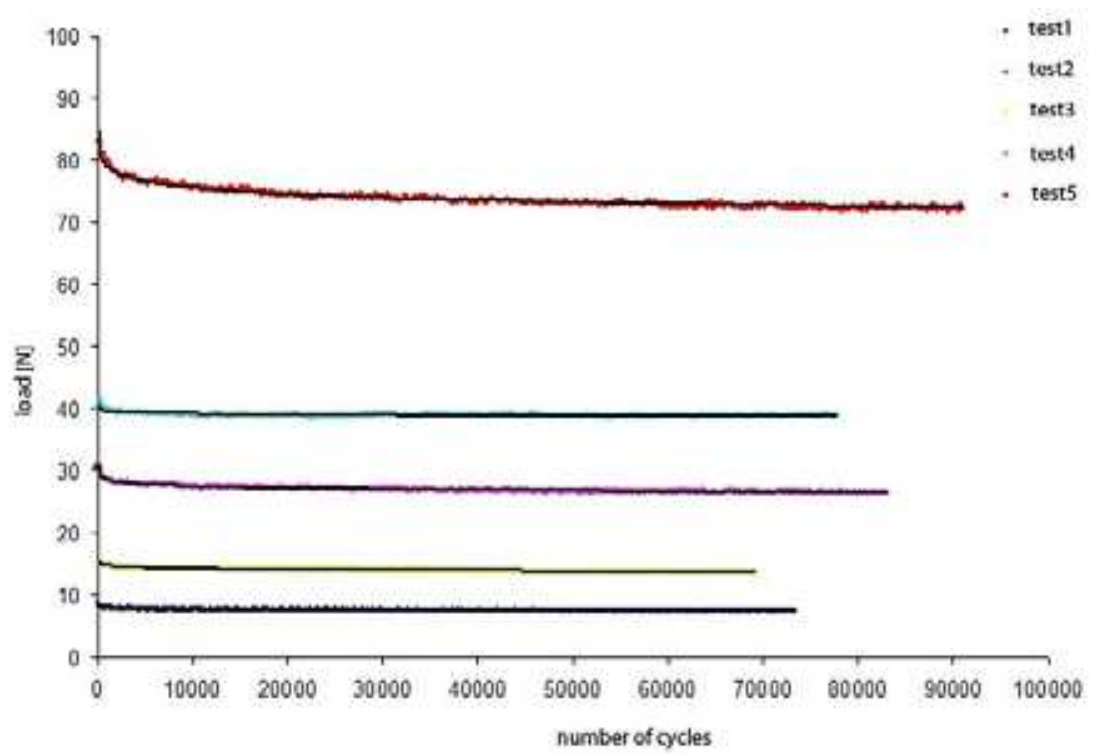

Fig. 19. Load curves versus the number of cycles (type b)

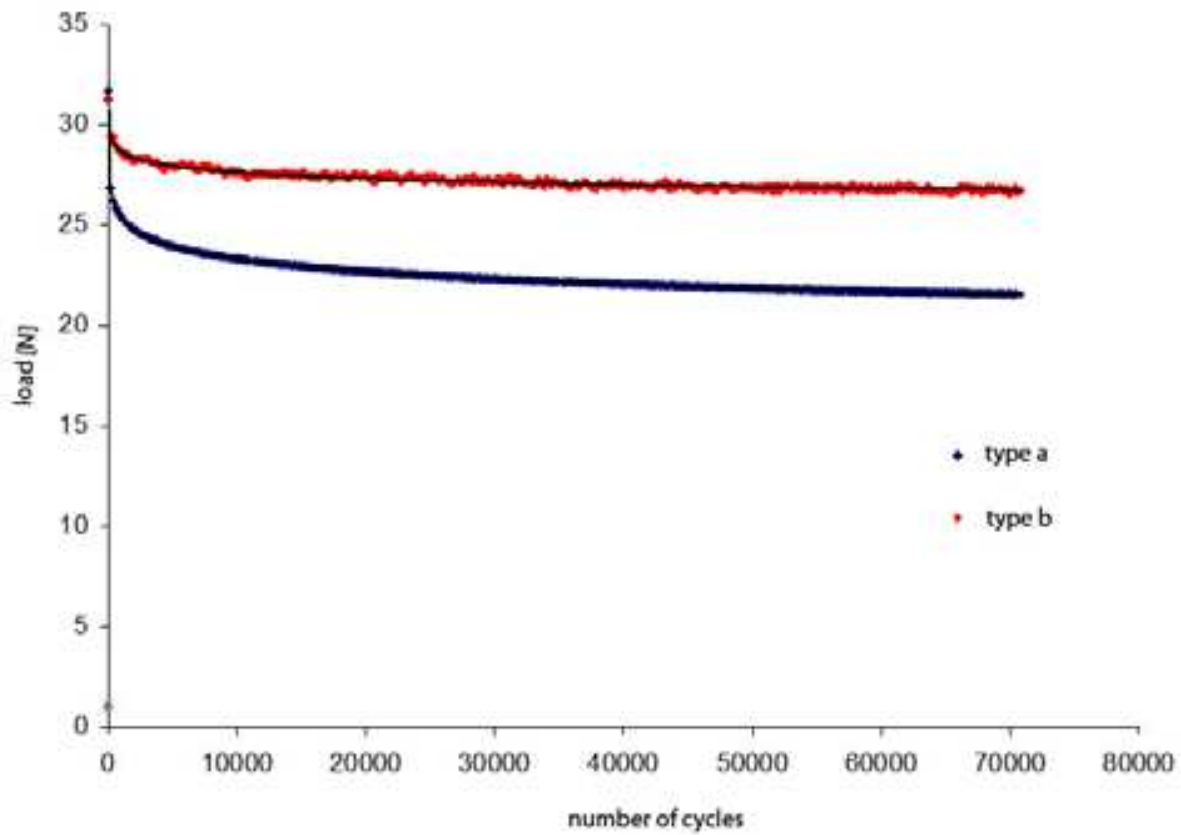

Fig. 20. Comparison of experimental curves for type (a) and type (b) tests under similar initial conditions 


\subsection{Third campaign of experimental test (bonded joints Al-Al)}

Specimens made of two aluminium layers 2024 T3 are used For MMELS tests (Mixed Mode End Load Split) and DP760 3M epoxy adhesive is used (Ducept, Gamby \& Davies, 1999;

Pirondi \& Nicoletto, 2001).

\begin{tabular}{|l|c|l|c|}
\hline \multicolumn{2}{|c|}{ epoxy adhesive } & \multicolumn{2}{c|}{ 2024 T3 aluminium alloy } \\
\hline Shear strength [MPa] & 28.2 & Ultimate strength [MPa] & 448 \\
\hline Peel strength [N/cm²] & 61.6 & Yield strength [MPa] & 310 \\
\hline Compressive strength [MPa] & 78.8 & Young modulus [MPa] & 73100 \\
\hline Young modulus [MPa] & 5972 & Poisson Ratio & 0.33 \\
\hline Poisson Ratio & 0.4 & & \\
\hline
\end{tabular}

Table 5. Mechanical and elastic properties

Epoxy adhesive is a bi-component product: the base (epoxy) and the accelerant (modified amine), it cures at room temperature and it has high temperature resistance (Higgins, 2000). The mixing ratio in volume of the two constituents is 2:1 and it is obtained through the use of 3M EPX applicator (Fig. 21). Table 5 shows the values of elastic properties and mechanical properties of the adhesive and of 2024 T3 aluminium alloy: The yield strength is the stress causing a permanent deformation $0.2 \%$.

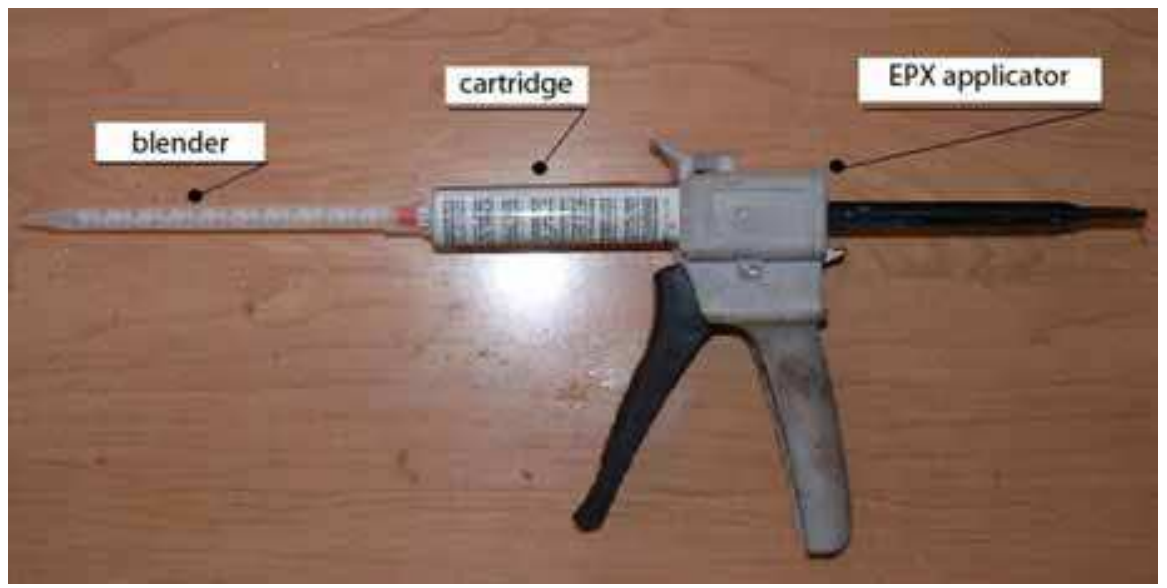

Fig. 21. EPX Applicator

The curing time is influenced by temperature and air humidity greatly, and decreases with increasing temperature and humidity. The minimum time recommended by $3 \mathrm{M}$ is 24 hours at room temperature followed by treatment in the oven for 1 hour at $80 \pm 2^{\circ} \mathrm{C}$ with subsequent slow cooling. The thickness of aluminium sheet is $3 \mathrm{~mm}$.

Tensile test is performed with a testing machine (Hounsfield) to determine elastic properties and $20 \mathrm{kN}$ load cell is used. Studied model is MMELS; all the same changes of geometric nature are done on the model for workshop necessity. 
The first change is done to transmit the displacement to the model: loaded sheet is longer than discharged sheet. Figure 22 shows the detail of the grasping between the specimen and the lever that applies the displacement. The second change is imposed by the full-scale load cell. The length of the specimen is increased to avoid the plasticization both of the load cell and of the model in the joint and to avoid to impose very small displacements. Figure 23 shows optimal size of model, obtained applying the beam theory. Total thickness is $B=20$ $\mathrm{mm}$, the thickness of loaded sheet is $\mathrm{h}_{1}=1.6 \mathrm{~mm}$, while the thickness of discharged sheet is $\mathrm{h}_{2}=3 \mathrm{~mm}$.

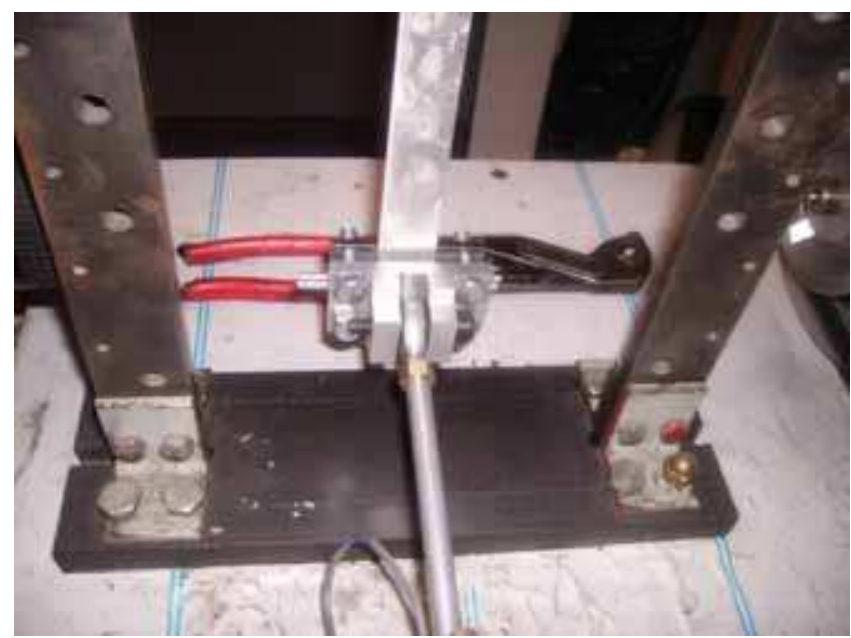

Fig. 22. System grasping between specimen and machine

Initial crack was created by interposing a Teflon layer between the two adherents (Figure 24). The thickness of Teflon is $50 \mu \mathrm{m}$, and then 4 Teflon layers are interposed to have desired thickness of adhesive layer (200 micron).

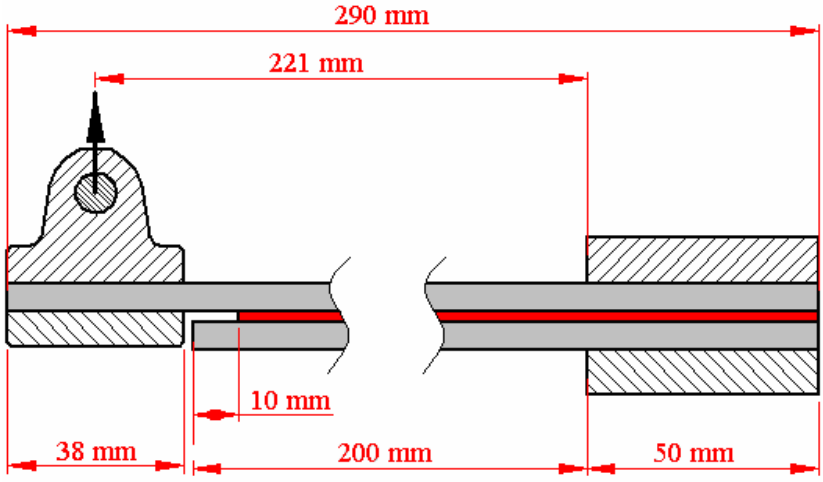

Fig. 23. Experimental model, loading and constraint system used for experimental tests

Fatigue tests were conducted on specimens that have different initial crack lengths $a_{0}$ and different imposed displacement (Table 6) (Blanco Villaverde, 2004). 


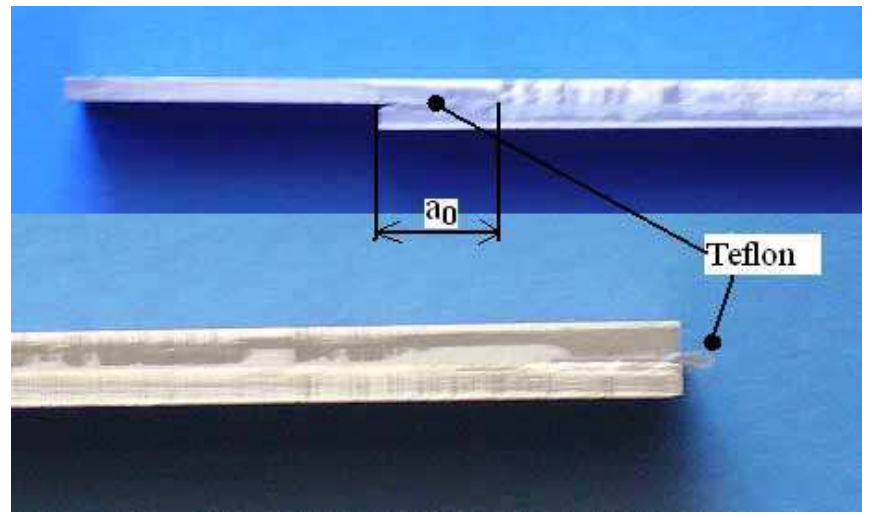

Fig. 24. Teflon layer interposed between adherents to create desired thickness and initial crack

Figure 25 shows that the load evolution can be divided into three zones. In the first area the load has a decreasing trend with increasing number of cycles; the specimen accumulates a small damage at the apex of the crack. The second area shows a sharp drop in the load due to rapid damage to the area near the apex of the crack (unstable defect propagation). In the third phase there is a very slow crack growth, which continues until complete delamination. The study of different curves shows that the specimen accumulates damage up to the break during load cycles (Sun \& Jih, 1987; Boniface \& Simha, 1999).

\begin{tabular}{|c|c|c|c|}
\hline \multirow{3}{*}{30} & $\mathrm{a}_{0}[\mathrm{~mm}]$ & $\begin{array}{c}\text { Imposed } \\
\text { displacement }[\mathrm{mm}]\end{array}$ & Inizial load [N] \\
\cline { 2 - 4 } & A & 11 & 29,5 \\
\cline { 2 - 4 } & B & 8,5 & 21.8 \\
\hline \multirow{3}{*}{35} & D & 7 & 17.9 \\
\cline { 2 - 4 } & E & 12,5 & 29,8 \\
\hline \multirow{3}{*}{40} & F & 12 & 27 \\
\cline { 2 - 4 } & G & 17 & 32,4 \\
\cline { 2 - 4 } & H & 9,5 & 25,4 \\
\hline \multirow{2}{*}{50} & I & 7 & 17.9 \\
\hline
\end{tabular}

Table 6. Experimental tests

Load-number of cycles curves were obtained (Fig. 25). 


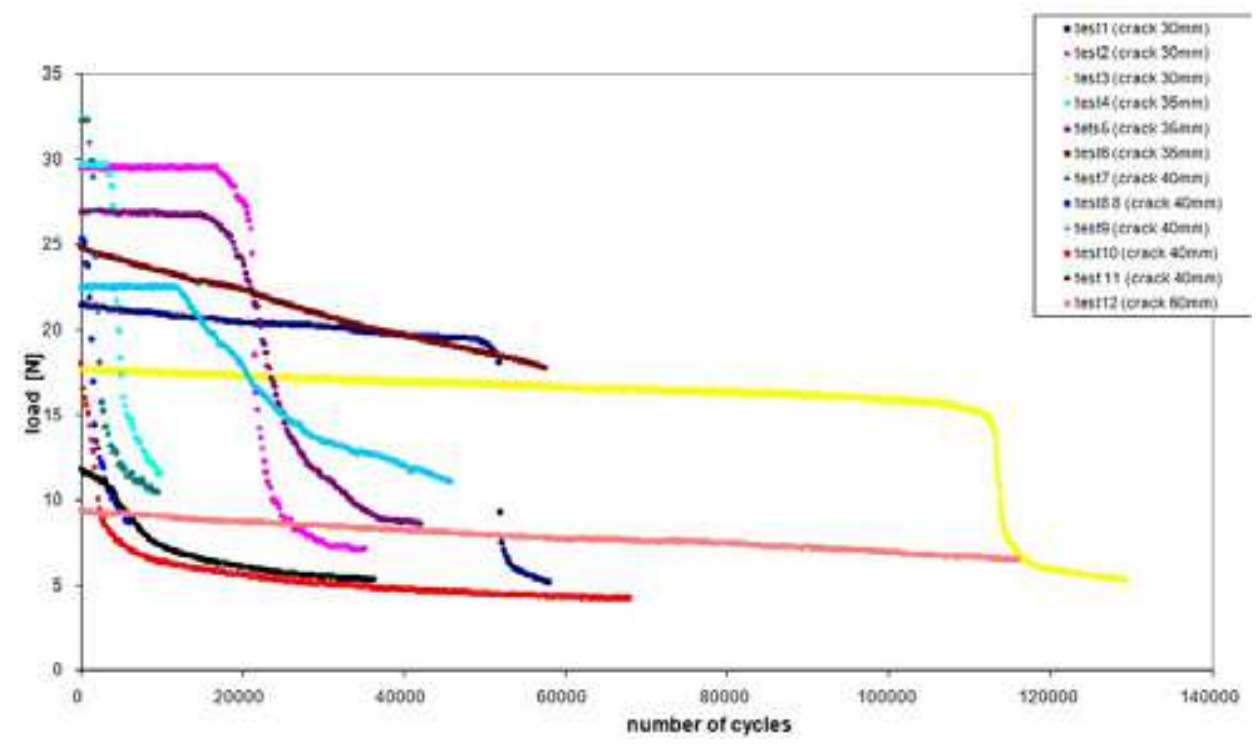

Fig. 25. Load-number of cycles curves of the bonded joints for different crack lengths

\section{Numerical results}

Experimental results are compared with those obtained by numerical simulations. The damage criterion has been implemented inside ANSYS code to evaluate current dimension of the defect varying the number of cycles; the mesh is implemented by square elements. External load is applied at the top of loaded layer; the constraints are placed in appropriate way to avoid axial tensions that change the ratio of mixed-mode failure.

Classic model (Sidoroff \& Subagio, 1987; Van Paepegem \& Degrieck, (a) 2001) for unidirectional composite fiberglass and epoxy resin (GLARE) subject to fatigue loads is applied, introducing the value of applied load instead of amplitude strain.

$$
\frac{d D}{d N}=\mid \begin{array}{cc}
\frac{A \cdot\left(\frac{\Delta \sigma}{\sigma_{T S}}\right)^{c}}{(1-D)^{b}} & \text { in tracion } \\
0 & \text { in compression }
\end{array}
$$

Stress and strain are linked together by the relationship:

$$
\sigma=E_{0} \cdot(1-D) \cdot \varepsilon
$$

Where $\mathrm{E}_{0}$ is the elastic modulus of non stressed material.

The parameter $D$ is the variable of local damage, $N$ the number of cycles, $\Delta \sigma$ is the amplitude of cyclic load applied, $\sigma_{T S}$ is ultimate tensile strength of the material, $A, b$ and $c$ are three coefficients depending on experimental material. Material constants are obtained by an optimization process applied to numerical simulation and the values are shown in table 7 . 


\begin{tabular}{|l|l|l|l|}
\hline Glare (type a) & $\mathrm{A}=0.1809 \mathrm{E}(-1)$ & $\mathrm{b}=0.7166$ & $\mathrm{c}=4.9896$ \\
\hline Glare (type b) & $\mathrm{A}=0.28010 \mathrm{E}(-2)$ & $\mathrm{b}=1.5631$ & $\mathrm{c}=11.125$ \\
\hline
\end{tabular}

Table 7. Material constants for GLARE specimens

The analysis of damage propagation in hybrid composite specimens is carried out considering only the degradation of composite laminates and neglecting the damage of aluminum sheet. Below some experimental-numerical comparisons are showed for specimens with one and two aluminum alloy sheets (Fig. 26).
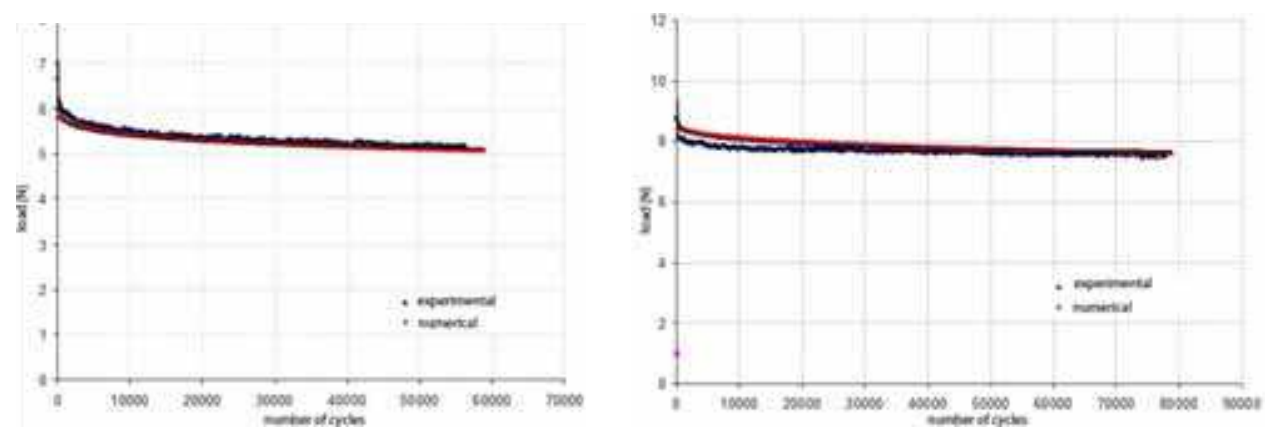

Fig. 26. Experimental-numerical results for GLARE specimens for one (on the left) and two (on the right) aluminium sheet

Propagation under conditions of mixed mode of opening (MMELS), as widely described in literature (Blanco et al., 2006), is modeled by a power law type:

$$
\frac{d a}{d N}=C \Delta G^{m}
$$

The following damage model is used in numerical analysis:

$$
\frac{d a}{d N}=\frac{c_{1}\left(e^{c_{2}\left(\frac{\Delta G}{G_{\text {crit }}}\right)^{c_{3}}}-1\right)}{c_{2}}\left(\frac{\Delta G}{G_{\text {crit }}}\right)^{c_{3}}
$$

The parameter $a$ is the crack length, $N$ the number of cycles, $\Delta \mathrm{G}$ is available energy at the peak of the defect, $\mathrm{G}_{\text {crit }}$ is the critical energy of the crack. The constants $c_{1}, c_{2}, c_{3}$ are obtained numerically by an extrapolation process according to the performance of G-a (energy-crack length) that are assumed a pattern of exponential growth. It is then used a classic pattern (Model Stirling) to hypothesize the evolution of the crack growth.

$$
\mathrm{c}_{1}=0,18 \mathrm{E}(-2) \quad \mathrm{c}_{2}=0,21 \quad \mathrm{c}_{3}=1,29
$$

Fig. 27 shows some experimental-numerical comparisons. 

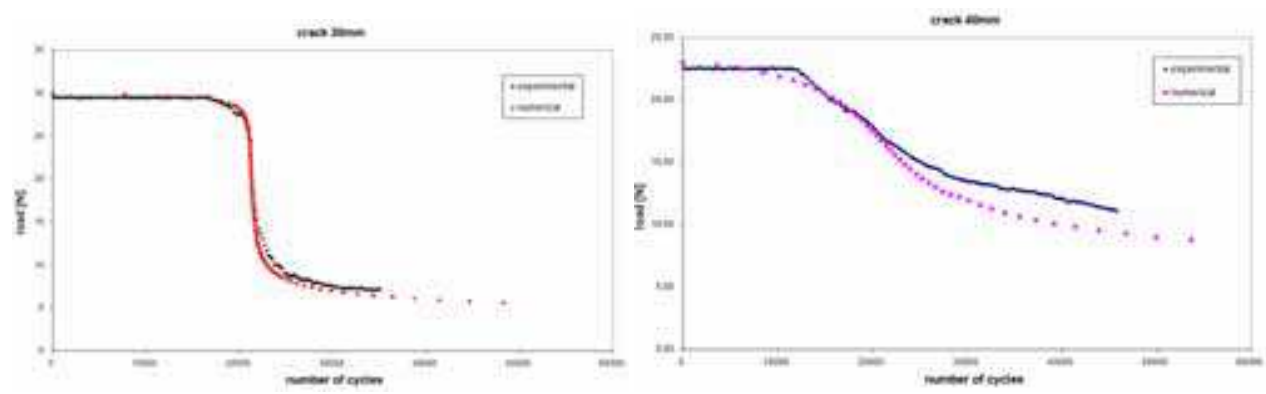

Fig. 27. Experimental-numerical results comparison for MMELS tests

\section{Conclusions}

During the project the machine is designed in very flexible way, choosing the load type, its size, its frequency, etc. So that fatigue tests on composite materials can be performed in operating conditions close to those of component in function. Analyzed specimens do not show subsidence or deformations after an initial visual inspection, but subsequent accurate observations show the presence (frequently) of the damage at interface between aluminium and composite layers.

Damage causes of a composite structure can be due to the application of fatigue loads (which determine the birth and propagation of cracks in sensitive areas) and the nucleation and propagation of interlaminar defects. These two types of damage can also coexist within structural element. Specimen damage after the initial phase of rapid growth tends to stop, this is due to the ability of redistribution of matrix-fibres composites to support stresses.

Then it is essential to analyze the degradation mechanisms because the stresses that are created near a geometrical discontinuity could promote the delamination propagation or break of the layer of matrix. A severe obstacle to the spread of composites is their high sensitivity to defects and the degradation. The tests have allowed to study very well the damage evolution and so to estimate operating conditions of structural element after applying a certain number of fatigue cycles.

Experimental study of MMELS model for bonded joints is conducted to determine the damage before the phase of unstable crack propagation and shows that defect propagation occurs at the interface between adhesive and loaded layer (adhesive fracture) in MMELS model. The damage accumulated in adhesive coat during the loading history was marked. Load-number of cycles curve has a slight negative slope during fatigue load. Adhesive coat downstream from the apex of the defect accumulate some damage that alter the bending stiffness of the specimen. Unstable phase of crack growth follows at stable phase which rapidly spreads within a few cycles until final break of the component. A good correspondence between experimental and numerical results is found in all the analyzed cases both to composite laminates and to bonded joints.

The results show that the machine FTM setup is able to carry out its task with testing costs quite content. The extension to the bonded joints is particularly interesting.

Future developments: the optimization of the machine can be done by replacing the base with a more rigid and larger in order to have a second engine, more powerful, to perform tests that require higher loads, with an appropriate load cell. Also it is appropriate to 
consider the creation of a load cell for lower loads than $10 \mathrm{~N}$, while eccentricity adjustment can be performed with micrometer spindle.

\section{References}

Beck, T., Lohe, D., Baumgartner, F., 2002, The Fatigue Behaviour of an Aluminium Foam Sandwich Beam Under Alternating Bending - Advanced Engineering Materials, vol. 4, n. 10, pp 787-790

Berchem, K., Hocking, M. G., 2006, A simple plane bending fatigue and corrosion testing machine, Design Note, Measurement Science and Technology 17 (10), art. no. N05, pp. N60-N66

Blanco Villaverde, N., 2005, Variable mixed-mode delamination in composite laminates under fatigue conditions : testing \& analysis [dirigida per Josep Costa Balanzat] Publicació Universitat de Girona, DL, ISBN 8468909904.

Blanco N., Gamstedt E. K., Costa J., Trias D., 2006, Analysis of the mixed-mode end load split delamination test, Composite Stuctures, vol. 76, 14-20

Boniface, V., Simha, K. R. Y. , 1999, Re-examination of crack opening model of interface fracture, Engineering Fracture Mechanics vol. 64, pp 677-691.

Caligiana, G., Minak, G., Ghezzo, F., Cicchetti, M., 2003, "Dispositivo per prove di fatica su materiali compositi: progetto, messa a punto e risultati sperimentali", XXXII Convegno Nazionale AIAS, Salerno 3-6 Settembre 2003, AIAS 2003

Ducept, F., Gamby, D., Davies P., 1999, A mixed-mode failure criterion derived from tests on symmetric and asymmetric specimens, Elsevier Composites Science and Technology, Vol. 59, pp. 609-619.

Froustey, C., Lasserre, S. 1989, Multiaxial fatigue endurance of 30NCD16 steel, International Journal of Fatigue 11 (3), pp. 169-175

Higgins, A., 2000Adhesive bonding of aircraft structures, International Journal of Adhesion $\mathcal{E}$ Adhesives Vol. 20, pp. 367-376.

Marannano, G. V., Pasta, A., Virzì Mariotti, G., 2007 Progetto e messa a punto di una macchina prova materiali a fatica a flessione piana per provini in composito XXXVI Convegno Nazionale AIAS, ISBN 978-88-87 998-75-7, 4-8 Settembre 2007, Ischia (Na), Italy

Marannano, G. V; Pasta, A., 2006. An analysis of interface delamination mechanisms in orthotropic and hybrid fibre-metal composites laminates - Engineering Fracture Mechanics. Vol. 74 (4). Pp. 612-626. ISSN: 0013-7944.

Marannano, G., Virzì Mariotti, G., 2008. Structural Optimization and Structural Analysis of Composite Material Panel for Naval Use - Meccanica, vol. 43, 2008, pp. 251-262 -. DOI: $10.1007 /$ s11012-008-9120-z. ISSN: 0025-6455.

Natarajan, V., GangaRao, H.V.S., Shekar, V. 2005. Fatigue response of fabric-reinforced polymeric composites. Journal of Composite Materials Vol. 39 (17), pp. 1541-1559

Pirondi A., Nicoletto G., 2001, Tenacità a frattura in Modo Misto I/II di giunti incollati- XXX Convegno Nazionale AIAS-Alghero (SS) 12-15 settembre 2001.

Robinson, P., Hodgkinson, J. M. , 2000, Interlaminar fracture toughness, in: Mechanical Testing of Advanced Fibre Composites, Editor(s): Hodgkinson, Cambridge, Woodhead Publishing Ltd., Pages: 170-210, ISBN:9780849308451

Sideroff, F., Subagio, B. (1987), Fatigue damage modelling of composite materials from bending test. Sixth International Conference on Composite Materials (ICCM-VI) \& 
Second European Conference on Composite Materials (ECCM-II): Volume 4. Proceedings, 20-24 July 1987,London, UK, Elsevier, pp. 4.32-4.39.

Sugeta, A., Uematsu, Y., Tomita, K., Hirose, K., Jono, M., 2006, Development of Fatigue Testing System for in-situ Observation by an Atomic Force Microscope and Small Fatigue Vrack Growth Behavior in a-Brass, JSME International Journal, Series A, vol. 49 , no.3, pp. 382-389

Sun, C. T., Jih, C. J., 1987, On strain energy release rates for interfacial cracks in bi-material media, Engineering Fracture Mechanics -Vol. 28, No.1, pp 13-20,.

Trotignon J. P. (1995). A New Universal Fatigue Machine for Plastics and Composites. Polymer Testing Volume: 14, Issue: 2, pp. 129-147.

Van Paepegem, W., Degrieck, J. (a) 2001. Fatigue degradation modelling of plain woven glass/epoxy composites, Composites - Part A: Applied Science and Manufacturing 32 (10), pp. 1433-1441.

Van Paepegem, W., Degrieck, J. (b) 2001. Experimental set-up for and numerical modelling of bending fatigue experiments on plain woven glass/epoxy composites. Composite Structures 51 (1), pp. 1-8

Van Paepegem, W., Degrieck, J. 2002. Coupled Residual Stiffness and Strength Model for Fatigue of Fibre-reinforced Composite Materials. Composites Science and Technology, 62(5), 687-696 (SCI-IF: 1.320).

Vasek, A., Polàk, J., Kozàk, V. 1997. Fatigue crack initiation in fibre-metal laminate GLARE 2. Materials Science and Engineering A 234-236, pp. 621-624. 


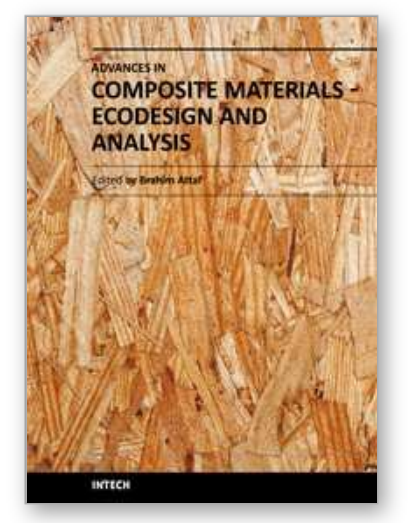

\author{
Advances in Composite Materials - Ecodesign and Analysis \\ Edited by Dr. Brahim Attaf
}

ISBN 978-953-307-150-3

Hard cover, 642 pages

Publisher InTech

Published online 16, March, 2011

Published in print edition March, 2011

By adopting the principles of sustainable design and cleaner production, this important book opens a new challenge in the world of composite materials and explores the achieved advancements of specialists in their respective areas of research and innovation. Contributions coming from both spaces of academia and industry were so diversified that the 28 chapters composing the book have been grouped into the following main parts: sustainable materials and ecodesign aspects, composite materials and curing processes, modelling and testing, strength of adhesive joints, characterization and thermal behaviour, all of which provides an invaluable overview of this fascinating subject area. Results achieved from theoretical, numerical and experimental investigations can help designers, manufacturers and suppliers involved with high-tech composite materials to boost competitiveness and innovation productivity.

\title{
How to reference
}

In order to correctly reference this scholarly work, feel free to copy and paste the following:

G. Di Franco, G. Marannano, A. Pasta and G. Virzi Mariotti (2011). Design and use of a Fatigue Test Machine in Plane Bending for Composite Specimens and Bonded Joints, Advances in Composite Materials - Ecodesign and Analysis, Dr. Brahim Attaf (Ed.), ISBN: 978-953-307-150-3, InTech, Available from:

$\mathrm{http}: / / w w w . i n t e c h o p e n . c o m / b o o k s / a d v a n c e s-i n-c o m p o s i t e-m a t e r i a l s-e c o d e s i g n-a n d-a n a l y s i s / d e s i g n-a n d-u s e-$ of-a-fatigue-test-machine-in-plane-bending-for-composite-specimens-and-bonded-joints

\section{INTECH}

open science | open minds

\section{InTech Europe}

University Campus STeP Ri

Slavka Krautzeka 83/A

51000 Rijeka, Croatia

Phone: +385 (51) 770447

Fax: +385 (51) 686166

www.intechopen.com

\section{InTech China}

Unit 405, Office Block, Hotel Equatorial Shanghai

No.65, Yan An Road (West), Shanghai, 200040, China

中国上海市延安西路65号上海国际贵都大饭店办公楼 405 单元

Phone: +86-21-62489820

Fax: $+86-21-62489821$ 
(C) 2011 The Author(s). Licensee IntechOpen. This chapter is distributed under the terms of the Creative Commons Attribution-NonCommercialShareAlike-3.0 License, which permits use, distribution and reproduction for non-commercial purposes, provided the original is properly cited and derivative works building on this content are distributed under the same license. 